\title{
Empirical assessment of loyalty drivers using consumers' retail format choice
}

\author{
1,2* Gindi, A. A., ${ }^{1}$ Abdullah, A. M., ${ }^{1}$ Ismail, M. M. and ${ }^{1}$ Nawi, N. M. \\ ${ }^{I}$ Department of Agribusiness and Bio-resource Economics, Faculty of Agriculture, \\ Universiti Putra Malaysia, 43400 UPM, Serdang, Selangor, Malaysia \\ ${ }^{2}$ Kebbi State University of Science and Technology, Aliero, Kebbi State, Nigeria, PMB 1144
}

\begin{abstract}
Article history:
Received: 9 February 2017

Received in revised form:

6 March 2017

Accepted: 8 March 2017

Available Online:

11 May 2017
\end{abstract}

\section{Keywords:}

Retail format

Loyalty drivers

Consumers

Fresh

Vegetable

DOI:

http://doi.org/10.26656/

fr.2017.3.020

\begin{abstract}
Using Stimulus-Organism-Response (S-O-R) framework, this study examines StimulusResponse relationships of fresh vegetable consumers' behavior in Klang Valley, Malaysia. In particular, the study focused on how loyalty drivers affect retail formats choice by the fresh vegetable (FV) consumers. The Stimuli that pertain to loyalty drivers include promotional activities, perceived price and social interaction and the Response is the retail format choice. Three hypotheses were developed and tested with the data collected from a survey using simple random sampling technique. Structural Equation Model (SEM) was used in analyzing the data. Results of the study revealed that Stimuli (loyalty drivers) influence Response (retail format choice) for the different FV markets in Malaysia. Based on the finding of the research, Malaysian retailers have different marketing strategies to be considered with regards to loyalty drivers.
\end{abstract}

\section{Introduction}

The Malaysian retail sector began with traditional neighborhood sundry shops, mini markets, night markets, wet markets and later convenience stores. The emergence of super and hyper retailers in 1990s has somewhat imposed pressure on small retailers. Shamsudin (2005) revealed that Malaysian has experienced tremendous growth of modern retail formats which are dominating over local or traditional retail outlets. To differentiate traditional retail formats from modern ones, the traditional market outlets have little control or organization, lack of refrigeration facilities, agglomeration of small vendors, where each vendor specializes in one fresh food line (either meat, fish, fruits or vegetables) or in a sub line of fruits and vegetables. Night market is one of the traditional markets and becomes entrenched in the Malaysian shopping scene. It is based on the concept of open-air shopping (Ishak et al., 2012), where street hawkers occupy a designated part of the street or parking lots to set up their stalls. Like others traditional markets, it allows customers to enjoy wide varieties and choices of fresh fruits and vegetables and non -agricultural products at affordable prices. In terms of operation time, it usually operates ones or twice in a week from $3 \mathrm{pm}$ till $10 \mathrm{pm}$ in the night. The sizes of markets depend on the number of the stalls. Large night markets would have between 400 to 700 stall lots, medium night markets between 241 to 399 stall lots while the small night markets could have between less than 50 to 240 stall lots. A farmers market is another type of traditional format in which farmers, growers from a local area are present in persons to sell their own product directly to the public. However in developing countries like Malaysia, the established farmers' markets are mostly mixed markets. In terms of product mix, farmers markets are normally dominated by fresh agricultural products including fishes. In contrast with night and farmers markets, wet market normally comprises stalls housed in fixed structure or a building with providing lots. House-liked structure with covered building and operates on daily basis between 6.30 am to lunch period. The traders generally focus on fish and sea foods, together with the local products providing a full range of fresh produce.

The modern retail outlets comprising supermarkets, hypermarkets, convenience or departmental stores have emerged in Malaysia in early 1990s (Worsley et al., 2010). Modern retail stores are self service offerings, space of the formats, product mix, and location of the formats are among the characteristics of the modern retail outlets. Retailing research council Asia Keith et al. (2006) differentiates between hypermarkets, supermarkets and convenience stores in terms of space and product mix. Hypermarkets having over 30.000 square feet 
and approximately 25.000 items while 5.000 to 30.000 square feet and 15.000 items for supermarkets and less than 3.000 square feet and fewer than 5.000 items for convenience stores.

Traditional markets constitute a place not only for purchasing perishable goods but also providing a place for meeting acquaintance (Chamhuri and Batt, 2009). Relationships are built between vendors and customers, and between customers. These relationships built between retailers and consumers have developed trust between both groups and it ensured customer loyalty to purchase from such retailers (Abu and Roslin, 2008). Chamhuri and Batt (2009) also showed the importance of social interaction at retail markets, stating that it provides a leisurely experience for consumers. Competitive price was mentioned as another reason for consumers to buy their FV from an outlet. In marketing, price is a powerful and convincing tool of attracting consumers to purchase at a particular retail outlet. There are different opinions of researchers on who offer lower prices to customers for FV purchase among retail formats. Farhangmehr and Silva (2000); Arshad and Darham (2012) have the opinion that modern retail outlets offer lower prices of FV than traditional markets. In Malaysia, focus group discussants believed that modern retail outlets sold $\mathrm{FV}$ at a much cheaper price compared to traditional retail outlets (Chamhuri and Batt, 2009). However, some researchers suggest that prices for FV are much cheaper in the traditional market. Goldman et al. (1999) mentioned that in Hong Kong, FV was perceived to be cheaper in most traditional markets. Berdegué et al. ( 2005) found that the prices of FV in modern retail outlets were $15-60 \%$ above that of traditional markets. Generally, retail outlets offering good quality products at lower price will attract consumers and will expect to be loyal to such retail outlets. Retailers are constantly engaged in promotional efforts that include "incentives" such as sales and discounts to attract consumers to their stores. Promotion helps to create public awareness of the activities of the retail outlets and increase the likelihood of patronage (Chze Lin and Lin Boon 2003). Promotion exposes consumers to the offering of stores, prime them with knowledge of the availability of the products that could cater to their future need and encourage their repeat visits and hence to be loyal to it.

According to Chen et al. (2012) on the research of automobile, presented the salient loyalty drivers including product type, sales personnel experience and service experience. Their argument is how to separate the few important loyalty drivers from the trivial once. Without understanding and identifying strong loyalty drivers, managers may apt to waste resources by improving on the loyalty drivers that contribute very little. In the field of marketing, loyalty is a commitment to repurchase a particular product/service and it is considered to be the highest level of relational bonding and maintains a long term relationship between customer and retailers (Chandrashekaran et al., 2007; Seggie et al., 2007; Li et al., 2009; Qi et al., 2009). Previous studies indicate the effect of shoppers' store choice behavior and found a positive impact on store choice and loyalty drivers and are critical determinants of successful retailing strategy (Bloemer and de Ruyter, 1998). Dick and Basu (1994) conceptualized loyalty as the relationships between relative attitude towards an entity (brand/services/store vendor) and patronage behavior of the consumers. Consumers become loyal to certain vendors/retailers from whom they expect good quality products and prices (Zinkhan et al., 1999). The important of personal interaction between vendors and customers with warm and friendly services eventually develops customer loyalty (Abu and Roslin, 2008). Research shows that the promotional practice on fresh produce can increase sales by 75 percent on average (McLaughlin, 2004). People who are more interested in price of food are likely to respond in quite different ways to fruit and vegetable promotions than those who are more interested in product quality. Ghosh et al. (2010) recommendations to the retailers on the various strategies that would meet the expectations of FV shoppers and thus motivate them towards store patronage decision indicated that promotional strategy is more important than other marketing strategies used by the retailers. Brennan and Lundsten (2000) analyzed the impact of large discount stores on small US towns found that consumers shop at discounters for low prices. Mittal and Mittal (2008) suggests that the retailers in marketing strategies have to take into account the attributes of loyalty drivers in order to attend an optimal retention and visitation of the customer to the retail outlets. Based on the above discussion, a positive relationship is expected between promotional activities, social interactions and retail format choice for FV purchases. However, a negative relationship is expected between perceived price and retail format choice and hence the model and hypotheses developed for this study is presented in Figure 1. 


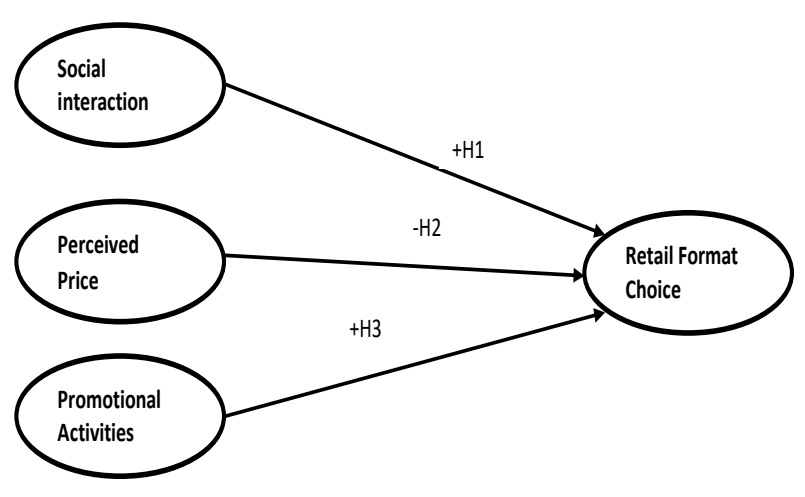

Figure 1. Model of retail format choice model

Hypotheses

$\mathrm{H} 1$ : Consumers choice toward FV retail format is influenced by social interaction obtained at a particular format.

$\mathrm{H} 2$ : Consumers choice toward FV retail format is influenced by perceived price of the products at that particular format.

H3: Consumers choice toward FV retail format is influenced by promotional activities offers at a particular format.

The aim of this study is to examine how loyalty drivers affect retail formats choice by the fresh vegetable $(\mathrm{FV})$ consumers.

\section{Materials and methods}

The study was conducted in Klang Valley area of Malaysia, within the period of three months from 5th June to 17th September, 2014. The area is geographically delineated by Titiwangsa Mountains to the north and east and the Strait of Malacca to the west. It extends to Rawang in the northwest, Semenyih in the southeast, and Klang and Port Klang in the southwest. The area was chosen for it is the most progressive area in the Peninsular Malaysia where businesses are flourishing and consumers comprise people from all walks of life in terms ethnicity, income level, reflecting different purchasing power, and education. The good mix of population will provide a good mixture of sample. Retail outlets both modern and traditional types are operating side by side competing for customers but sometimes complementing each other in terms of product offering. Cluster sampling technique was employed, involving the clustering of the entire population in to six clusters. The clusters include Kuala Lumpur, Putra Jaya, Petaling District, Klang, Gombak and Hulu Langat. In each cluster, one city area was randomly selected. The second stage in obtaining the sample size is the use of systematic random sampling and the main advantage of using the method is that it could be used without having the list of basic sampling units as in a situation where the dwellings were well organized in rows, blocks or along a river or main road (Saunders et al., 2009). A total of 700 respondents were randomly selected as the sample size. A standard questionnaire was designed and used as the survey and data gathering instrument. In the questionnaire, respondents were presented with the list of statements (items) which gathered from literatures sought to be the loyalty drivers considered by the respondents in makings decision to buy FV at retail format. A seven point Likert scale was used where respondents were required to indicate the extent of their agreement on each statement, as ' 1 ' was strongly disagree to ' 7 ' was strongly agree. Exploratory factor analysis was employed by grouping the items into the following factors; perceived price of the product, promotional activities and social interaction (Gindi et al., 2015) of the 16 items adopted from Arshad and Darham (2012) used in measuring these three loyalty driver variables. Respondents were requested to indicate their degree of agreement on each of 16 statements in choosing retail format for fresh fruits and vegetables purchases. Examples of the statements were "I always concerned with the store that provides quality products at lower price", "discount options offers influences my decision in choosing store" and "friendly staff assistance is the key in my retail outlets selections". The yielded factors were then confirmed by the confirmatory factor analysis and structural equation modeling was applied to test the proposed hypotheses. Data was analyzed using SPSS version 21 Software and Amos graphic software for Structural Equation Modeling (SEM)

\section{Results and discussion}

\subsection{Profile of respondents}

The profiles of respondents are depicted in Table 1. An almost balanced in gender of respondents, that is $51 \%$ male and $49 \%$ female were interviewed. The majorities (54\%) of the respondents were in the age group of between 18 to 35years, followed by 34 percent within the group between 36 to 50 years and only 12 percent were above 50 years of age. Most of the respondents were well educated where $75 \%$ were university and college graduates and the balance $25 \%$ had received secondary and primary school education. Although they are educated but 
most of them are relatively young and thus most of the respondents are in the middle income class, represented by $69.5 \%$ of the respondents.

Table 1. Demographic characteristics of the respondents

\begin{tabular}{lcc}
\hline Variables & Frequency & Percent \\
\hline Gender & 356 & 50.9 \\
Male & 344 & 49.1 \\
Female & & \\
Marital Status & 352 & 50.3 \\
Single & 348 & 49.7 \\
Married & & \\
Educational Level & 16 & 2.3 \\
Primary & 154 & 22.0 \\
Secondary School & 530 & 75.7 \\
Collage/ & & \\
University & & \\
Income (RM/Month) & 214 & 30.6 \\
Less or equal & & \\
3,000 & 326 & 46.6 \\
$3001-4000$ & 160 & 22.9 \\
4001 - 7000 & & \\
Age group (Years) & 378 & 34.0 \\
18-35 & 239 & \\
$36-50$ & 83 & \\
$>50$ & & \\
\hline Source, field survey, 2014 & & \\
& &
\end{tabular}

Structural equation modeling was developed from the measurement models of the retail formats based on theoretical interrelationships among latent variables. Figure 2 below is the SEM results of standardized estimates of night market choice model. The focus of the SEM is not to test construct validity of the latent variables, rather to examine and test relationship between hypothesized exogenous and endogenous variables.

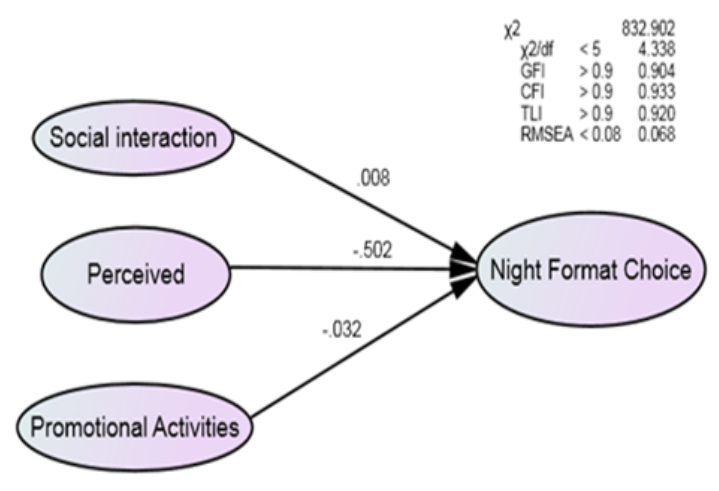

Figure 2. SEM result of night market choice model

\subsection{Model fit indices of fresh vegetables retail format choice models}

Model fit indices of the relationships between retail format choice for fresh vegetable purchase and loyalty drivers are presented in Table 2. Night market choice model has the following indices: Chi-square $(\chi 2)=832.902$, relative chi-square $(\chi 2 / \mathrm{df})=4.338$, $\mathrm{GFI}=0.904, \mathrm{CFI}=0.933, \mathrm{TLI}=0.920$ and $\mathrm{RMSEA}=$ 0.068 . The model fit indices of loyalty drivers for wet market choice model, farmers' market choice model, supermarket choice model and hypermarket choice model; all the model fit indices meet the requirement of acceptable values.

The results of SEM analysis are shown in Table 3. Perceived price had negative and significant effect on night market choice with $\beta=-0.502$ and significant at $99 \%$ confidence level, hence hypothesis 2 is supported. The loyalty drivers of promotional activities, perceived price and social interaction of consumers all are statistically significant on fresh wet market choice for fresh vegetable purchase with following regression weights: $\beta=0.347, \mathrm{p}=$ $0.0001 ; \beta=-0.121, p=0.048$; and $\beta=0.143, p=$ 0.031 respectively. For loyalty drivers predictors of farmers market choice, social interaction of consumers is statistically significant and has positive effect on farmers market choice for fresh vegetable purchase with regression weights of $\beta=0.154$, and $p$ $=0.013$. Perceived price has negative and statistical effect on supermarket choice $(\beta=-0.415, p=0.0001)$, hypothesis 2 is supported. As presented in Table 3, all the predictors of loyalty drivers have significant effect on hypermarket choice for fresh vegetable purchase.

\section{Conclusion}

Loyalty drivers of promotional activities and social interactions are not significant as presented in Table 3, but perceived price is negatively significant for the night market choice. The summary of results of hypotheses testing is presented in table 4. Unlike night market choice, wet market choice, all the three hypotheses were supported. On the other hand, only hypothesis 1 of the farmers market was supported. The interpretation of this could be farmers markets were established with given priority to freshness of the product rather than other marketing strategies of loyalty drivers. Almost the same situation was found at supermarket where hypotheses 1 and 3 are not supported. The explanation could be promotional activities for fresh vegetables at supermarkets may yield the perception to the vegetable consumers that 
Table 2. Model fit indices of retail format choice models of fresh vegetable

\begin{tabular}{lcccccc}
\hline \multicolumn{1}{c}{ Indices } & Criteria & $\begin{array}{c}\text { Night Market } \\
\text { Choice Model }\end{array}$ & $\begin{array}{c}\text { Wet Market } \\
\text { Choice Model }\end{array}$ & $\begin{array}{c}\text { Farmers Market } \\
\text { Choice Model }\end{array}$ & $\begin{array}{c}\text { Supermarket } \\
\text { Choice Model }\end{array}$ & $\begin{array}{c}\text { Hypermarket } \\
\text { Choice Model }\end{array}$ \\
\hline$\chi^{2}$ & & 832.902 & 805.859 & 721.407 & 716.337 & 726.316 \\
$\chi 2 / \mathrm{df}$ & 4.338 & 4.264 & 3.837 & 3.831 & 3.863 \\
GFI & $>0.9$ & 0.904 & 0.910 & 0.915 & 0.915 & 0.915 \\
CFI & $>0.9$ & 0.933 & 0.933 & 0.943 & 0.942 & 0.940 \\
TLI & $>0.9$ & 0.920 & 0.918 & 0.930 & 0.928 & 0.926 \\
RMSEA & $<0.08$ & 0.068 & 0.067 & 0.063 & 0.063 & 0.063 \\
\hline
\end{tabular}

Table 3. SEM results of fresh vegetables purchases at different retail formats

\begin{tabular}{lccccccc}
\hline \multicolumn{1}{c}{ Constructs } & Path & Constructs & $\begin{array}{c}\text { Unstandardized } \\
\text { Regression Weight } \\
\text { Estimate }(B)\end{array}$ & S.E. & $\begin{array}{c}\text { Standardized } \\
\text { Regression Weight } \\
\text { Estimate }(\beta)\end{array}$ & C.R. & P \\
\hline Night Market Choice & $<---$ & Promotional Activities & -.034 & .078 & -.032 & -.437 & .662 \\
Night Market Choice & $<---$ & Perceived Price & -.584 & .074 & -.502 & -7.908 & $* * *$ \\
Night Market Choice & $<---$ & Social Interaction & .012 & .098 & .008 & .119 & .905 \\
Wet Market Choice & $<---$ & Promotional Activities & .295 & .064 & .347 & 4.593 & $* * *$ \\
Wet Market Choice & $<---$ & Perceived Price & -.112 & .057 & -.121 & -1.974 & .048 \\
Wet Market Choice & $<---$ & Social Interaction & .173 & .080 & .143 & 2.158 & .031 \\
Famers Market Choice & $<---$ & Promotional Activities & .067 & .077 & .056 & .861 & .389 \\
Famers Market Choice & $<---$ & Perceived Price & -.012 & .070 & -.009 & -.176 & .860 \\
Famers Market Choice & $<---$ & Social Interaction & .297 & .120 & .154 & 2.477 & .013 \\
Supermarket Choice & $<---$ & Promotional Activities & -.045 & .048 & -.075 & -.945 & .345 \\
Supermarket Choice & $<---$ & Perceived Price & -.280 & .056 & -.415 & -4.961 & $* * *$ \\
Supermarket Choice & $<---$ & Social Interaction & .014 & .072 & .014 & .187 & .852 \\
Hypermarket Choice & $<---$ & Promotional Activities & .181 & .069 & .168 & 2.612 & .009 \\
Hypermarket Choice & $<---$ & Perceived Price & -.040 & .063 & -.034 & -.642 & .521 \\
Hypermarket Choice & $<---$ & Social Interaction & .244 & .107 & .141 & 2.289 & .022 \\
\hline
\end{tabular}

the product may have stayed for long period in chilled storage and retailers want to clear stocks as to reduce losses from spoilage and deterioration.

Loyalty drivers influencing consumer's retail format choice differ between retail formats. For the night market, wet market and supermarket for example, reduction of the vegetable prices by 1 units will influence choices of night market, wet market and supermarket by $0.502,0.121$ and 4.15 units respectively. Reducing FV price will make FV customers more patronizing these retail formats and consequently become loyal to these retail formats. For the hypermarket retailers, more emphasis should be given to promotional activities as well as improving the social interactions of the FV customers and between customers and retailers. Unlike other retail formats, farmer's market retailers of the farmer's formats should put more emphasis on other marketing strategies other than loyalty drivers for patronizing and retention of their FV customers.

\section{Reference}

Abu, N. K. and Roslin, R. M. (2008). Identifying service quality dimensions by understanding consumer preferences in the Malaysian grocery retail secto. Unitar E-Journal, 4(2), 57-67.

Arshad, F. M. and Darham, S. (2012). Parallel Mixed Mode Surveys on Consumer Attitude towards Fresh Produce. Business and Management Research, 1(3), 51-60.

Berdegué, J. A., Balsevich, F., Flores, L. and Reardon, T. (2005). Central American supermarkets' private standards of quality and safety in procurement of fresh fruits and vegetables. Food Policy, 30(3), 254-269.

Bloemer, J. and de Ruyter, K. (1998). On the relationship between store image, store satisfaction, and store loyalty. European Journal of Marketing, 32, 499-513.

Brennan, D.P. and Lundsten, L. (2000). Impacts of Strategies for Organized Retailers in Semi-Urban Large Discount Stores on Small US Towns: Reasons for Shopping and Retailer Strategies. International Journal of Retail and Distribution Management, 28(45), 155-161. 
Chamhuri, N. and Batt, P. J. (2009). Factors influencing consumers 'choice of retail stores for fresh meat in Malaysia. Paper presented at 19th Annual World Food and Agribusiness Forum and Symposium, 20-23 June 2009, Budapest Hungary.

Chandrashekaran, M., Rotte, K., Tax, S. and Grewal, R. (2007). Satisfaction strength and customer loyalty. Journal of Market Research, 44(1), 153-163.

Chen, J. Q., Yong, P. Z. and Wen, J. (2012). Are customer satisfaction and customer loyalty drivers of customer lifetime value in mobile data services : a comparative cross-country study. Information Technology Management, 13, 281-296.

Chze Lin D. T., and Lin Boon B. T. (2003). Linking Consumer Perception to Prefernces of Retail Stores: An empirical assessment of the Multi -Attributes of Store Image. Journal of Retailing and Consumer Services, 10, 193-200.

Dick, A. and Basu, K. (1994). Customer loyalty: toward an integrated conceptual framework. Academy of Marketing Science, 22(2), 99 - 113.

Farhangmehr, M., Marques, S. and Silva, J. (2000). Consumer and retailer perceptions of hypermarkets and traditional retail stores in Portugal. Journal of Retailing and Consumer Services, 7(4), 197-206.

Gindi, A. A., Abdullah, A. M., Ismail, M. M. and Nawi, N. M. (2015). Segmentation of Fresh Vegetable Shoppers by Product and Store Attributes Consedered for Fresh Vegetable Purchase in Klang Valley, Malaysia. IOSR Journal of Agriculture and Veterinary Science Ver. II, 8(2), 2319-2372.

Goldman, A., Krider, R. and Ramaswami, S. (1999). The Persistent Competitive Advantage of Traditional Food Retailers in Asia: Wet Markets' Continued Dominance in Hong Kong. Journal of Macromarketing, 19(2), 126-139.

Gosh, A., Tripathi, P. and Kumar, V. (2010). Customer Mall Expectations of store attributes and shopping value: Differences by Gender Retail outlets in India. Journal retail and Leisure Property, 7(1), 75-87.

Ishak, N. K., Aziz, K. A. and Ahmad, A. (2012). Dynamism of a night market. Journal of Case Research in Business and Economics, 4(1), 1-16.

Li, J., Wang, K.L. and Xu, L. (2009). Chameleon based on clustering feature tree and its application in customer segmentation. Annals of Operations Research, 168(1), 225-245.

McLaughlin, E. W. (2004). The dynamics of fresh fruit and vegetable pricing in the supermarket channel. Preventive Medicine, 39 Suppl 2, S81-87.

Mittal, A. and Mittal, R. (2008). Store Choice in the Emerging Indian Apparel Retail Market: An Empirical Analysis. International Black Sea University Scientific Journal, 2(2), 21-46.

Qi, J.Y., Zhang, L., Liu, Y.P., Li, L., Zhou, Y.P., Liang, L. and Li, H. (2009). ADTrees logit model for customer churn prediction. Annals of Operations Research, 168(1), 247-265.
Shamsudin, M. (2005) Changing Retail Food Sector in Malaysia. PECC Pacific Food System Outlook 2005 -06 Annual Meeting Kun Ming, China.

Saunders, M., Lewis, P. and Thornhill, A. (2009 or 2003?). Research Methods for Business Students. Research methods for business students. $3^{\text {rd }}$ ed. Harlow: FT/ Prentice Hall

Seggie, S., Cavusgil, E. and Phelan, S. (2007). Measurement of return on marketing investment: a conceptual framework and the future of marketing metrics. Industrial Marketing Management, 36, 834841.

Worsley, A., Wang, W. C. and Hunter, W. (2010). Baby boomers' food shopping habits. Relationships with demographics and personal values. Appetite, 55(3), 466-72.

Zinkhan, G. M., Fontenelle, S. M. and Balazs, A. L. (1999). The Structure of Siio Paulo Street Markets : Evolving Patterns of Retail Institutions. Journal of Consumer Affairs, 33(1), 3-26. 